\title{
Review of Philosophy of economics (Handbook of the Philosophy of Science, Volume 13) edited by Uskali Mäki. North Holland: Elsevier, 2012, 902 pp.
}

\author{
LAWRENCE A. BOLAND \\ Simon Fraser University
}

The primary intended audience for this Handbook is philosophers who might be enticed to consider economics as a subject for analysis. As the editor says, "Economics has characteristics that make it a particularly inviting target and playground for philosophical argument and analysis" (p. xiii). He goes on to say that a "possible source of philosophical reflection and debate is the emergence of new theories or research techniques that challenge more established ways of doing economics" and that "recently, the initiatives of experimental, behavioural and neuroeconomics have launched methodological debate and research, with philosophical arguments designed and used either to justify the new approaches or to question them" (p. xiv).

To accomplish his task, the editor has divided the Handbook into two separate parts. Part A is a collection of papers by authors who are well versed in the philosophy of economics, some of whom are also familiar with the methodology of economics (I separate these because they are not the same-for example, one can study the methodology of economics without ever discussing the philosophy of economics). Part B consists of some papers by practicing economists who are willing to consider a philosophical aspect to their field of expertise, and some papers by philosophers who have an interest in economics. Part A seems to be pleading with philosophers to take an interest in economics, as philosophers of science are interested in say physics. Part B seems to be directed at demonstrating how the philosophy of economics can be done.

Despite the intended philosophical audience, there are many good papers in this volume that are worth reading by ordinary economists without an overt interest in the philosophy of economics. Of course, I am one of that type of reader and I will here be considering it from this perspective. But before I do that, let me summarise what can be found in the two parts. 
Part A is identified as "General philosophical themes" and Part B is identified as "Specific methods, theories, approaches, paradigms, schools, traditions". The "philosophical themes" of Part A include such issues as realism (a topic that few economists ever talk about), causation (a topic most economists take for granted), models versus theories (a topic that would not be understood by the younger generations of economics [see Boland forthcoming]), naturalism (usually a question about whether economics can be considered a science like physics-a topic few economists find interesting) and the associated nature of economic explanations (a topic that economists should be interested in but very few are), the role of mathematics (a topic few if any economists find interesting), feminist philosophy (a topic that the male-dominated economics academic community should be interested in but few males are), the old positive versus normative dichotomy (a hot topic among a few methodologists today, but not well understood by practicing economists), economics as ideology (another go at the topic of whether economics can be considered a science), and the role of experimentation (still another attempt to deal with the topic of the extent that economics can be scientific). As my parenthetical comments indicate, I think few economists would find a need to consider what is discussed in Part A. But the editor is probably right that many philosophers of science might.

The papers in Part B are easier for those trained in economics, such as I am. It begins with two practicing economists talking directly about "The philosophy of economic forecasting", and the "Philosophy of econometrics". A later paper, similarly, discusses the "Philosophy of game theory". Not all of the authors in the second part are practicing economists, although three have two PhDs, whereby they started with a philosophy $\mathrm{PhD}$ and finished with one in economics. Some are philosophers of science outright and I guess are included to demonstrate how to do proper philosophy of economics.

If the book's intended purpose lies in interesting philosophers of science to consider looking closer at economics, I am not sure the chapters by practicing economists who are willing to consider philosophical aspects of their sub-discipline will convince them. (Although, should the economists in this part do a poor job, it might convince some philosophers to try to do it better.) The reason is that most, if not all, of the practicing economists included here are not really talking about philosophy of science (beyond their introductory 
observations), but are instead talking about topics of interest to methodologists of economics.

It is true that some philosophers think that any talk of methodology is inherently philosophical. But, as I noted already, one can talk about methodology without ever engaging in philosophical analysis. D. McCloskey $(1985,159-162)$ made this point thirty years ago by distinguishing between 'big-M' methodology that involves questions of interest to philosophers and 'small-m' methodology that involves questions of interest to practicing economists (usually about model building methods).

The only 'philosophical themes' discussed in Part A that are explicitly discussed by the authors in Part B are causality (briefly), the nature of explanations and the nature and use of models (versus theories). Almost all of the authors in Part B are talking mostly about small-m methodological questions with little explicit reference to philosophy. There is only one chapter in Part B that includes any significant discussion of the views of philosophers of science, though two chapters give a prominent role to the views of Karl Popper (which seems clearly to contradict the argument of Chapter 2, that Popper's views are no longer relevant to economics). It is left to some of the philosophers of science to indulge in examining non-conventional (i.e., non-neoclassical) models of economic behaviour-this seems intended to indicate to other philosophers of science that there are interesting (i.e., non-stale) questions outside of neoclassical economics that might be worthy of philosophical analysis. That includes a couple of papers that have less to do with discussing either the philosophy or the methodology of economics and more to do with the methodology of political science or sociology.

Now, I have always been suspicious of 'Handbooks of' but this one does have many chapters that many economists should find interesting and useful in their research. Whether this volume will be successful in its intended goal of attracting philosophers to the study of the philosophy of economics I am not so sure. Not because of any lack of quality in the included chapters (all seem good at what they do), but because of a major cultural gap between how philosophers and non-philosophers view research activity in social and natural science: the big-M versus small-m views of what matters in methodological research which distinguishes the interests of the philosophers (Part A) from the interests of economists (Part B). It is difficult to see that many 
would-be new philosophers of economics would find much of interest in the small-m methodology discussed in Part B, particularly given the general absence in Part B of big-M methodology discussions that might be of interest to philosophers.

It is unfortunate that philosophers promoting the philosophy of economics too often see any discussion of the cultural gap as an attempt to reinforce disciplinary biases and divisions. But the gap is real, as we see in this volume's separation between Parts A and B, where the 'philosophical themes' which philosophers think are essential are hardly mentioned let alone discussed in Part B. Hopefully this book will be successful in attracting some new philosophers of science to the study of economic methodology, but that is only first step. Unless these philosophers want to be accused of what some might call "philosophical imperialism", they need to recognize the "big-M versus small-m" cultural gap that McCloskey was warning them about 30 years ago and that is well illustrated in this book. If one's interest in methodology stems from seeing a need for helping practicing economists with their small-m problems, particularly those problems with roots in philosophy, then the challenge is to discuss methodology in such a way that practicing economists will pay attention and maybe even learn something about philosophy of science. And, if one's interest in methodology stems from seeing interesting philosophical problems in the work of economists, then the challenge is to discuss big- $M$ methodology in a way that contributes to the philosophy of science.

\section{REFERENCES}

Boland, Lawrence. Forthcoming. Model building in economics: purposes and limitations. Cambridge: Cambridge University Press.

McCloskey, D. N. 1985. The rhetoric of economics. Madison: University of Wisconsin Press.

Lawrence Boland has been teaching economics for almost 50 years. From the beginning, his research has been about the methodology of economics-in particular, about why economists assume what they do. He is the author of what will soon be seven books about the methodology of economics including The foundations of economic methodology ([1982] 2003); The principles of economics: some lies my teachers told me (1992); Critical economic methodology (1997); and the forthcoming Model building in economics: its purposes and limitations. Contact e-mail: <boland@sfu.ca> 